\title{
The Mechanisms of hsp27 Antibody-Mediated Apoptosis in Retinal Neuronal Cells
}

\author{
Gülgün Tezel and Martin B. Wax \\ Department of Ophthalmology and Visual Sciences, Washington University School of Medicine, St. Louis, Missouri 63110
}

Although elevated titers of serum antibodies to hsp27 accompany human diseases such as cancer and glaucoma, evidence of their pathogenic effects is lacking. Here we present novel evidence that exogenously applied hsp27 antibody enters neuronal cells in human retina by an endocytic mechanism. Subsequent to internalization, hsp27 antibody facilitates apoptotic cell death as characterized by morphological assessment, DNA fragmentation, and the activation of cysteine aspartic acid proteases. In addition, we demonstrate that after internalization, hsp27 antibody is detected in discrete cytoplasmic and nuclear structures and colocalizes to actin cytoskeleton. Hsp27 antibody binding to actin results in depolymerization and proteolytic cleavage of actin in a dose-dependent manner. These results suggest that exogenous hsp27 antibody may induce neuronal apoptosis by inactivating or attenuating the ability of native hsp27 to stabilize actin cytoskeleton, thereby providing a novel mechanism by which autoantibodies to hsp27 may impair cell survival in selective human diseases.

Key words: actin; antibody; apoptosis; caspase; heat shock protein 27; retina
Controversial evidence suggests that autoantibodies can penetrate living cells, subsequently alter cellular function associated with their intracellular target antigens, and cause apoptosis in several autoimmune diseases (Alarcon-Segovia and Lorente, 1983; Reichlin, 1995, 1998; Alarcon-Segovia et al., 1996; Yanase et al., 1997). Elevated serum titers of antibodies against hsp27 have been documented in several human diseases, including cancer (Conroy et al., 1998) and glaucoma (Tezel et al., 1998). In the case of glaucoma, there is compelling evidence that the presence of elevated serum antibodies to hsp27 may have pathogenic importance. First, most glaucoma patients typically demonstrate a prominent and progressive atrophy of the retinal pigment epithelium adjacent to the optic nerve head. We have proposed that these parapapillary defects of the outer blood-retina barrier may allow communication and access of circulating antibodies to the retina, a tissue that is normally privileged except in certain disease states (Wax et al., 1998). Second, the expression of hsp27 in the retinal ganglion cells is upregulated in glaucomatous eyes (Tezel et al., 2000). Last, exogenously applied hsp27 antibody, at concentrations similar to those found in glaucoma patients, facilitates apoptotic cell death in retinal cells in culture (Tezel et al., 1998). However, the intracellular events by which hsp 27 antibody may participate in cell death have not been established.

Here, we studied cellular entry and intracellular effects of hsp27 antibody in retinal cells, ex vivo and in vitro. Our observations provide novel evidence that exogenously applied hsp27

Received Aug. 17, 1999; revised Feb. 22, 2000; accepted March 6, 2000.

This study was supported in part by Grant EY12314 from the National Eye Institute (M.B.W.), The Glaucoma Foundation (G.T.), and an unrestricted grant to Washington University School of Medicine, Department of Ophthalmology and Visual Sciences, from Research to Prevent Blindness Inc., New York. We thank Dr. Gail M. Seigel for kindly providing E1A.NR3 retinal cell line, Dr. David D. Chaplin for P-55-knockout mice, Dr. Thomas A. Ferguson for fas-knockout mice, Dr. Raj Patil for DNA sequencing of knockout mice, and Zelma Jones for excellent assistance during electron microscopy.

Correspondence should be addressed to Dr. Martin B. Wax, Department of Ophthalmology and Visual Sciences, Washington University School of Medicine, Box 8096, 660 South Euclid Avenue, St. Louis, MO 63110. E-mail: wax@vision.wustl.edu.

Copyright (c) 2000 Society for Neuroscience $\quad 0270-6474 / 00 / 203552-11 \$ 15.00 / 0$ antibody enters neuronal cells in human retina by an endocytic mechanism. Subsequent to internalization, hsp27 antibody facilitates apoptotic cell death as characterized by morphological assessment, DNA fragmentation, and the activation of cysteine aspartic acid proteases (caspases). In addition, we demonstrate that after internalization, hsp27 antibody is detected in discrete cytoplasmic and nuclear structures, and colocalizes to actin cytoskeleton. Hsp27 antibody binding to actin results in depolymerization and proteolytic cleavage of actin in a dose-dependent manner. These findings suggest that actin microfilament breakdown is a key event in retinal neuronal apoptosis induced by elevated hsp27 antibody titers.

\section{MATERIALS AND METHODS}

Isolated retina. Three pairs of human eyes from donors (ages 56, 61, and 64 years) with no history of eye disease were obtained from the MidAmerica Eye and Tissue Bank (St. Louis, MO) within 6 hr after death. We also used retinas from eyes of genetically engineered mice, which were deficient in TNF- $\alpha$ receptor-1 (P-55 knockout) (provided by Dr. D. D. Chaplin, Washington University, St. Louis, MO), TNF- $\alpha$ receptor-2 (P-75 knockout) (The Jackson Lab, Bar Arbor, Maine), or fas (lpr) (provided by Dr. T. A. Ferguson, Washington University), and control mice (C57BL/6) (Harlan, Indianapolis, IN). The specificity of knockout mice was confirmed by PCR (Hanley and Merlie, 1991). After enucleation, the eyes were rinsed with $\mathrm{CO}_{2}$-free culture medium (Life Technologies, Grand Island, NY) chilled in $4^{\circ} \mathrm{C}$, and retinas were mechanically dissected under a microscope. Full-thickness retina pieces of 5 $\mathrm{mm}$ diameter from the midperipheral zone were cut using a trephine and used immediately for experiments.

The cellular viability in the isolated retinas was assessed using an intracellular esterase activity kit (Molecular Probes, Eugene, OR) that relies on the calcein cleavage activity of intracellular esterase within living cells to form a green fluorescent membrane-impermeable product. After flattening of the isolated retina with a coverslip to allow dye to penetrate the entire tissue adequately, approximately 750 cells chosen from three random areas were counted at $200 \times$ magnification by means of fluorescent microscopy. The viability was expressed as a ratio of the number of esterase-positive cells to total number of cells counted and multiplied by 100 , which was $96.10 \pm 3.6 \%$.

Isolated retina specimens were incubated in DMEM in the presence or absence of mouse monoclonal antibody against hsp27 (IgG1) $(100 \mu \mathrm{g} / \mathrm{ml})$ (Stress Gen, Victoria, Canada), mouse monoclonal antibody against IgG 
(IgG1) (Fc specific) $(100 \mu \mathrm{g} / \mathrm{ml})$, or mouse monoclonal antibody against calbindin-D $(100 \mu \mathrm{g} / \mathrm{ml})$ (Sigma, St. Louis, MO) in a tissue culture incubator with humidified atmosphere of $5 \% \mathrm{CO}_{2}$ and $95 \%$ air at $37^{\circ} \mathrm{C}$ for $30 \mathrm{~min}$ or 2,6 , or $12 \mathrm{hr}$. A competition experiment was performed in which isolated retinas were preincubated with purified human hsp27 (100 $\mu \mathrm{g} / \mathrm{ml}$ ) (Stress Gen) for $1 \mathrm{hr}$ before the incubation with hsp27 antibody. To examine the role of $\mathrm{Fc}$ receptors, isolated retinas were also preincubated with $\mathrm{Fc}$ fragments from human IgG (Chemicon, Temecula, CA) at a concentration of $200 \mu \mathrm{g} / \mathrm{ml}$ for $1 \mathrm{hr}$ before the incubation with hsp27 antibody. At the end of the incubation period, the retinas were processed for fluorescence microscopy using the terminal deoxynucleotidyl transferase-mediated dUTP nick end labeling (TUNEL) or immunoelectron microscopy.

Retinal cell culture. An immortalized rat retinal cell line (E1A.NR3) (provided by Dr. G. M. Seigel, University of Rochester, Rochester, NY) that contains cells expressing antigens specific for photoreceptors, bipolar cells, ganglion cells, and retinal glial cells (Seigel, 1996) was maintained in DMEM supplemented with $10 \%$ fetal bovine serum and $1 \%$ each of nonessential amino acids, L-glutamine, vitamins, and antibiotics (Life Technologies).

Retinal cells plated on six-well plates (Costar, Cambridge, MA) at a density of $3 \times 10^{4}$ cells per well were cultured in the presence of monoclonal hsp27 antibody $(50-200 \mu \mathrm{g} / \mathrm{ml})$ or monoclonal anti-IgG (100 $\mu \mathrm{g} / \mathrm{ml}$ ) for $24 \mathrm{hr}$. To examine the role of complement, cells incubated in a medium containing heat-inactivated fetal bovine serum were similarly processed. A competition experiment was performed in which various concentrations of purified hsp27 $(10-200 \mu \mathrm{g} / \mathrm{ml})$ were added to culture medium $1 \mathrm{hr}$ before the incubation with hsp27 antibody. To examine the role of caspases in the apoptotic process induced by hsp27 antibody, retinal cells were also incubated with hsp27 antibody in the presence of the caspase inhibitors boc-aspartyl(Ome)-fluoromethylketone (B-DFMK; $50 \mu \mathrm{M}$ ) (Thornberry et al., 1992; Graybill et al., 1994; Boudreau et al., 1995) or CBZ-Ile-Glu(Ome)-Thr-Asp-(Ome)-fluoromethylketone (Z-IETD-FMK; $20 \mu \mathrm{M}$ ) (Mashima et al., 1995a) (Enzyme System Products, Livermore, CA). After incubation, the cells were examined using TUNEL or flow cytometry, or their extracts were used in Western blot analysis and in vitro caspase activity assays. Experiments were repeated at least three times for each condition.

Immunoelectron microscopy. Tissues were fixed in modified Karnovsky's fixative $(2.5 \%$ glutaraldehyde and $2 \%$ paraformaldehyde in 0.1 M cacodylate buffer, $\mathrm{pH} 7.4$ ) at $4^{\circ} \mathrm{C}$ overnight. They were post-fixed in phosphate-buffered $2 \%$ osmium tetroxide for $1 \mathrm{hr}$ at room temperature. Fixed tissues were then dehydrated in a graded series of ethyl alcohol $(30-100 \%)$ and embedded in Epon 812. Thin (80-90 nm) sections placed on $2 \times 1 \mathrm{~mm}$ nickel grids were incubated with $4 \%$ dry milk solution prepared in $0.05 \mathrm{M}$ Tris, $\mathrm{pH} 7.4$, for blocking nonspecific binding. They were then incubated in $0.05 \mathrm{~m}$ Tris $-1.5 \%$ bovine serum albumin, $\mathrm{pH} 8.3$, containing anti-IgG conjugated with $10 \mathrm{~nm}$ gold particles (dilution, 1:12) (Sigma) for $1 \mathrm{hr}$. Grids were sequentially rinsed in $0.05 \mathrm{M}$ Tris- $0.2 \%$ bovine serum albumin, $0.05 \mathrm{M}$ Tris, and distilled water, and counterstained with uranyl acetate and lead citrate. Sections were examined using a transmission electron microscope (Jeol, Tokyo, Japan).

To examine the colocalization of internalized hsp27 antibody with the actin cytoskeleton, isolated retinas incubated in the presence or absence of monoclonal mouse antibody against hsp 27 were placed on nickel grids and blocked using $4 \%$ dry milk for $20 \mathrm{~min}$. Retinas were then incubated with rabbit antibody against actin (Sigma) in 0.05 M Tris- $1 \%$ bovine serum albumin, $\mathrm{pH} 7.4$, for $2 \mathrm{hr}$. After grids were rinsed in Tris solution, they were incubated in $0.05 \mathrm{M}$ Tris- $1.5 \%$ bovine serum albumin, $\mathrm{pH} 8.3$, containing both anti-mouse IgG conjugated with $10 \mathrm{~nm}$ gold particles and anti-rabbit IgG conjugated with $5 \mathrm{~nm}$ gold particles (dilutions, 1:12) (Sigma) for $1 \mathrm{hr}$. The grids were then rinsed and counterstained as described above.

TUNEL. An in situ cell death detection kit (Boehringer Mannheim, Mannheim, Germany) was used to identify apoptotic cells in human retina. Briefly, after deparaffinization, $4-\mu \mathrm{m}$-thick sections of the human retina were incubated with a mixture of fluorescein-labeled nucleotides and terminal deoxynucleotidyl transferase for $1 \mathrm{hr}$. The slides were examined using a fluorescence microscope (Olympus, Tokyo, Japan). Incubation with fluorescein-labeled nucleotide mixture without the presence of terminal deoxynucleotidyl transferase was used as a negative control. Treatment with Dnase I $(1 \mathrm{mg} / \mathrm{ml})$ to induce breaks in the DNA strands served as a positive control. In addition, to study cell types positive for TUNEL, the retinal sections were immunolabeled using monoclonal antibodies to neuron specific enolase, neurofilament protein, or glial fibrillary acidic protein (Chemicon).

Flow cytometry. For the quantification of DNA fragmentation (Dolzhanskiy and Basch, 1995; Moore et al., 1998), the trypsinized cells were fixed with $2 \%$ paraformaldehyde solution for $20 \mathrm{~min}$ at room temperature. After washing, cells were incubated with $0.1 \%$ Triton X-100 prepared with sodium citrate for $4 \mathrm{~min}$ at $4^{\circ} \mathrm{C}$. After washing, cells were incubated with a mixture of fluorescein-labeled nucleotides and terminal deoxynucleotidyl transferase for $1 \mathrm{hr}$ (Boehringer Mannheim). Cells incubated with fluorescein-labeled nucleotide mixture without the presence of terminal deoxynucleotidyl transferase served as a negative control. Cells previously treated with Dnase I $(1 \mathrm{mg} / \mathrm{ml})$ to induce breaks in the DNA strands served as a positive control.

To analyze the effect of hsp27 antibody on the intracellular dynamic equilibrium between actin forms in retinal cells by flow cytometry (Howard and Meyer, 1984), cells were double-stained with phalloidinfluorescein isothiocyanate (Wulf et al., 1979) $(0.2 \mu \mathrm{M})$ and Dnase I-Texas Red (Hitchcock, 1980) (0.3 $\mu \mathrm{M})$ (Molecular Probes) for $20 \mathrm{~min}$ after fixation and permeabilization steps to label polymeric and monomeric actin, respectively. The cells were then washed and resuspended at $10^{6}$ cells $/ \mathrm{ml}$.

The stained cells were analyzed using a FACScan flow cytometer/ CELLQuest Software system (Becton Dickinson, San Jose, CA). Fluorescein isothiocyanate fluorescence intensity and Texas Red fluorescence intensity were measured on excitation at 488 and $597 \mathrm{~nm}$, respectively, at constant intensity voltage in all experiments. Data were collected using logarithmic amplification on 10,000 cells, excluding cell debris, by a combination of forward and side scatters. Measurement gates were set using the negative controls. Frequency histograms of labeled cells are presented.

Western blotting. The retinal cells were lysed in sample buffer (1\% SDS, $100 \mathrm{~mm}$ DTT, $60 \mathrm{~mm}$ Tris, pH 6.8, 0.001\% bromophenol blue). Protein concentrations were determined using the BCA method (Sigma). Samples were boiled $5 \mathrm{~min}$ before subjecting them to electrophoresis. Samples $(50 \mu \mathrm{g}$ of total protein) were separated by electrophoresis in $10-15 \%$ SDS polyacrylamide gels at $160 \mathrm{~V}$ for $1 \mathrm{hr}$ and electrophoretically transferred to polyvinylidene fluoride membranes (Millipore, Marlboro, MA) using a semi-dry transfer system (Bio-Rad, Hercules, CA). After transfer, membranes were blocked in a buffer $(50 \mathrm{~mm}$ Tris $\mathrm{HCl}, 154 \mathrm{~mm}$ $\mathrm{NaCl}, 0.1 \%$ Tween-20, pH 7.5) containing 5\% nonfat dry milk for $1 \mathrm{hr}$, then overnight in the same buffer containing a dilution of primary antibody and sodium azide. Primary antibodies were monoclonal antibodies to caspase-8 (1:1000) (PharMingen, San Diego, CA) or actin (1:500) (Sigma) or polyclonal antibody to caspase-3 (1:1000) (PharMingen). After several washes and a second blocking for $20 \mathrm{~min}$, the membranes were incubated with secondary antibodies conjugated with horseradish peroxidase (Fisher, Pittsburgh, PA) (1:2000) for $1 \mathrm{hr}$. Immunoreactive bands were visualized by enhanced chemiluminescence using commercial reagents (Amersham, Arlington Heights, IL).

In vitro caspase-3 assay. Caspase-3-like protease activity was measured in a fluorometric assay by measuring the extent of cleavage of the fluorometric peptide substrate as described previously (Bump et al., 1995, Deshmukh et al., 1996). Briefly, the cells were lysed in buffer A (10 mM HEPES, pH 7.4, $42 \mathrm{~mm} \mathrm{KCl,} 5 \mathrm{~mm} \mathrm{MgCl}, 1 \mathrm{~mm}$ DTT, 0.5\% CHAPS, 1 $\mathrm{mM}$ PMSF, and $1 \mu \mathrm{g} / \mathrm{ml}$ leupeptin). Lysate was then combined in a 96-well plate with buffer B (25 mM HEPES, pH 7.5, 1 mM EDTA, 3 mm DTT, $0.1 \%$ CHAPS, and $10 \%$ sucrose) containing Ac-Asp-Glu-Val-Asp7-amino-4-trifluoro-methyl coumarin $(50 \mu \mathrm{M})$. Positive controls included purified recombinant caspase-3 $(0.1 \mu \mathrm{g})$ (Upstate Biotechnology, Lake Placid, NY). Fluorescence was measured at an excitation wavelength of $360 \mathrm{~nm}$ and an emission wavelength of $460 \mathrm{~nm}$ in a fluorescent plate reader at different time points up to $180 \mathrm{~min}$. Protease activity was expressed as picomole of substrate per milligram of protein per minute as calculated relative to the activity of the control samples using the linear range of the assay and normalized for protein concentrations of individual extracts.

\section{RESULTS}

\section{Internalization of hsp27 antibody}

In isolated human retina, exogenous application of monoclonal mouse antibody to human hsp27 resulted in internalization in both neuronal and glial cells as detected by immunogold labeling at discrete cytosolic sites (Fig. 1). In contrast, labeling of tissue was absent in control retina incubated in the absence of antibody 

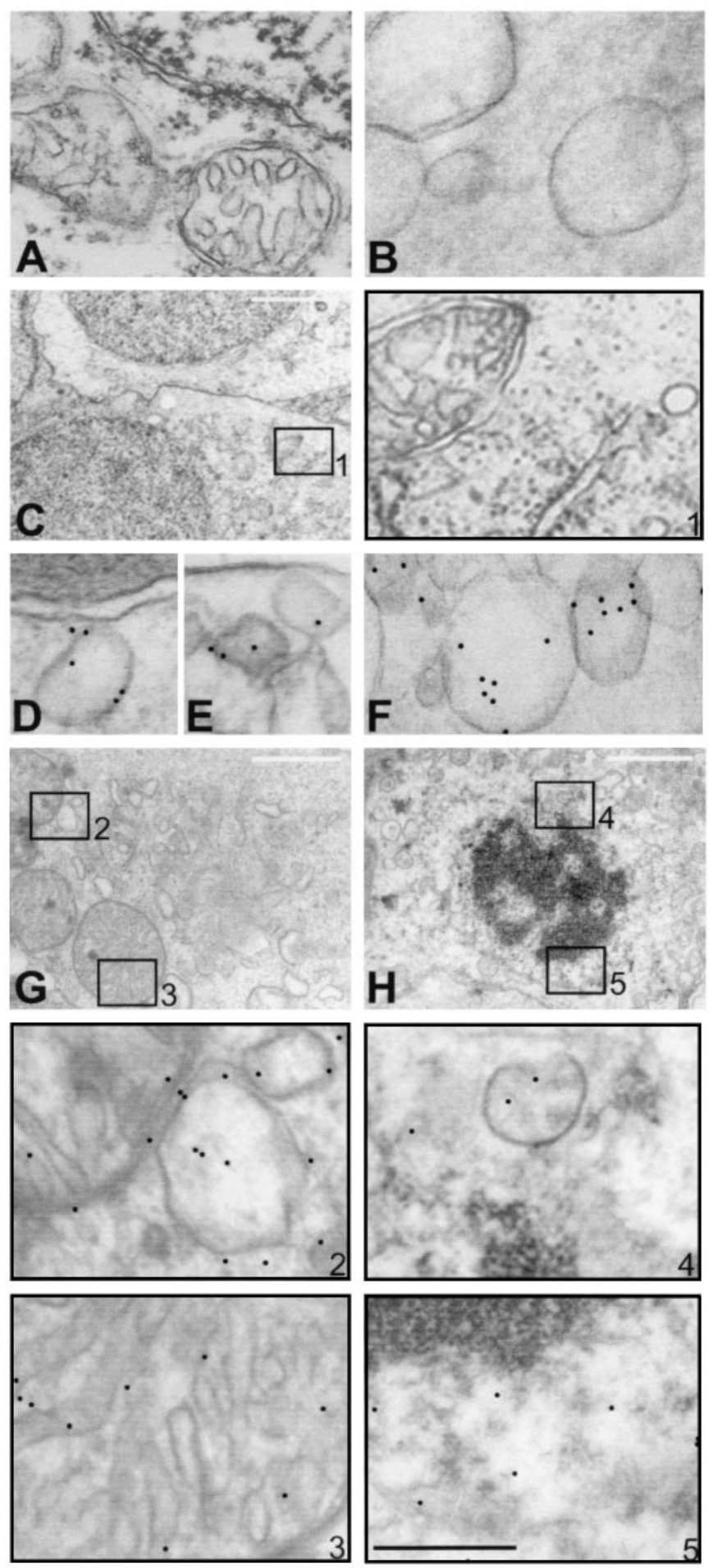

Figure 1. Internalization of hsp27 antibody by human retina observed by immunogold labeling and electron microscopy. No gold particles were observed within neuronal cells in control retina incubated without antibody $(A)$ or incubated with control antibodies, anti-IgG $(B)$, or anticalbindin-D $(C)$. $C$, Micrograph of retinal ganglion cells after incubation with calbindin-D antibody for $12 \mathrm{hr}$. Higher magnification micrograph of selected area in $A$ is shown in box 1 , which indicates negative gold labeling. However, after incubation with hsp27 antibody, intracellular gold particles were observed in a time-dependent pattern. Immunolabeling was positive in endosomes $(D, E)$ and vesicles $(F)$ of the retinal ganglion cells incubated with hsp27 antibody for $30 \mathrm{~min}$. Micrographs of two retinal cells incubated with hsp27 antibody for 6 and $12 \mathrm{hr}$, respectively, are shown in $G$ and $H$. Higher magnification micrographs of
(Fig. 1A). Using control mouse antibodies, anti-IgG or anticalbindin-D, immunogold labeling was negative in retinal neuronal cells (Fig. $1 B, C$ ). The internalization of exogenously applied hsp27 antibody exhibited a time-dependent pattern. In retina incubated with hsp27 antibody for $30 \mathrm{~min}$, immunogold labeling was detected mainly at cell surface invaginations, pits, and membrane-associated endosomes (Fig. 1D,E). In retina incubated with hsp27 antibody for $2 \mathrm{hr}$, gold particles were also observed in intracellular structures. However, after incubation with hsp27 antibody for 6 or $12 \mathrm{hr}$, gold particles were no longer detected at the cell surface and were mostly observed in vesicles, multivesicular bodies, lysosomes, and mitochondria (Fig. $1 F-H$ ). Immunogold labeling was also detected in perinuclear areas and in the nuclei (Fig. 1H). Immunogold labeling was observed in all layers of retinal neuronal cells, including ganglion cells, inner nuclear layers (bipolar, horizontal, and amacrine cells) and outer nuclear layers (photoreceptors). Quantification of gold particles in a masked fashion revealed approximately 300 gold particles per neuronal cell in retinas incubated with hsp27 antibody, whereas the number of gold particles seen in neuronal cells was less than 10 per grid in control retinas incubated either with control antibodies or without antibody.

After incubation with hsp27 antibody, gold particles also appeared clustered in patches throughout the cytoplasm. Double immunolabeling demonstrated that the cytoplasmic binding of hsp27 antibody corresponds to actin cytoskeleton. Immunoelectron microscopy exhibited prominent colocalization of internalized hsp27 antibody to actin cytoskeleton within 2-6 hr of exogenous application (Fig. 2). In addition, electron microscopic examination revealed a marked shortening and disorganization of actin microfilaments in human retinal cells incubated with hsp27 antibody for 6-12 hr (Fig. 2C).

\section{Induction of apoptosis}

After incubation of human retina with hsp27 antibody, characteristics of apoptotic cell death were detected in retinal neuronal cells by both morphological assessments using electron microscopy and TUNEL using fluorescence microscopy. To examine cell type positive for TUNEL, human retina sections were immunolabeled for neuronal and glial cell markers. In addition, well characterized morphological features assessed by electron microscopy assisted the recognition of retinal cell types exhibiting features of apoptotic cell death (Hollander et al., 1991).

Electron microscopy revealed that the ganglion cells in isolated human retina incubated with hsp27 antibody exhibited characteristic features of apoptotic cell death (Fig. 3). These morphological features included shrunken cytoplasm and pyknotic nuclei with condensation of nuclear chromatin and, in some cells, frank absence of nuclear membrane with a dense residuum of nuclear material. The cell membrane was intact, and the cytoplasmic contents were condensed. Organelles remained generally intact even when the cells were transformed to apoptotic bodies con-

$\leftarrow$

selected areas in $G$ and $H$ are shown in boxes with corresponding numbers. Boxes 2 and 3 show mitochondrion and vesicules, and boxes 4 and 5 show perinuclear area. After incubation with hsp 27 antibody for 6 or $12 \mathrm{hr}$, gold particles were mostly observed in vesicular structures of various size and mitochondria $(G, H)$. In addition, perinuclear areas and nuclei of the retinal cells incubated with hsp27 antibody exhibited immunogold labeling $(H)$. Notice the double membrane and internal cristae of mitochondria in $G$ and condensed nuclear chromatin in $H$. Black scale bar: $A, B, D-F, 0.5 \mu \mathrm{m}$; white scale bar: $C, G, H, 2 \mu \mathrm{m}$. 


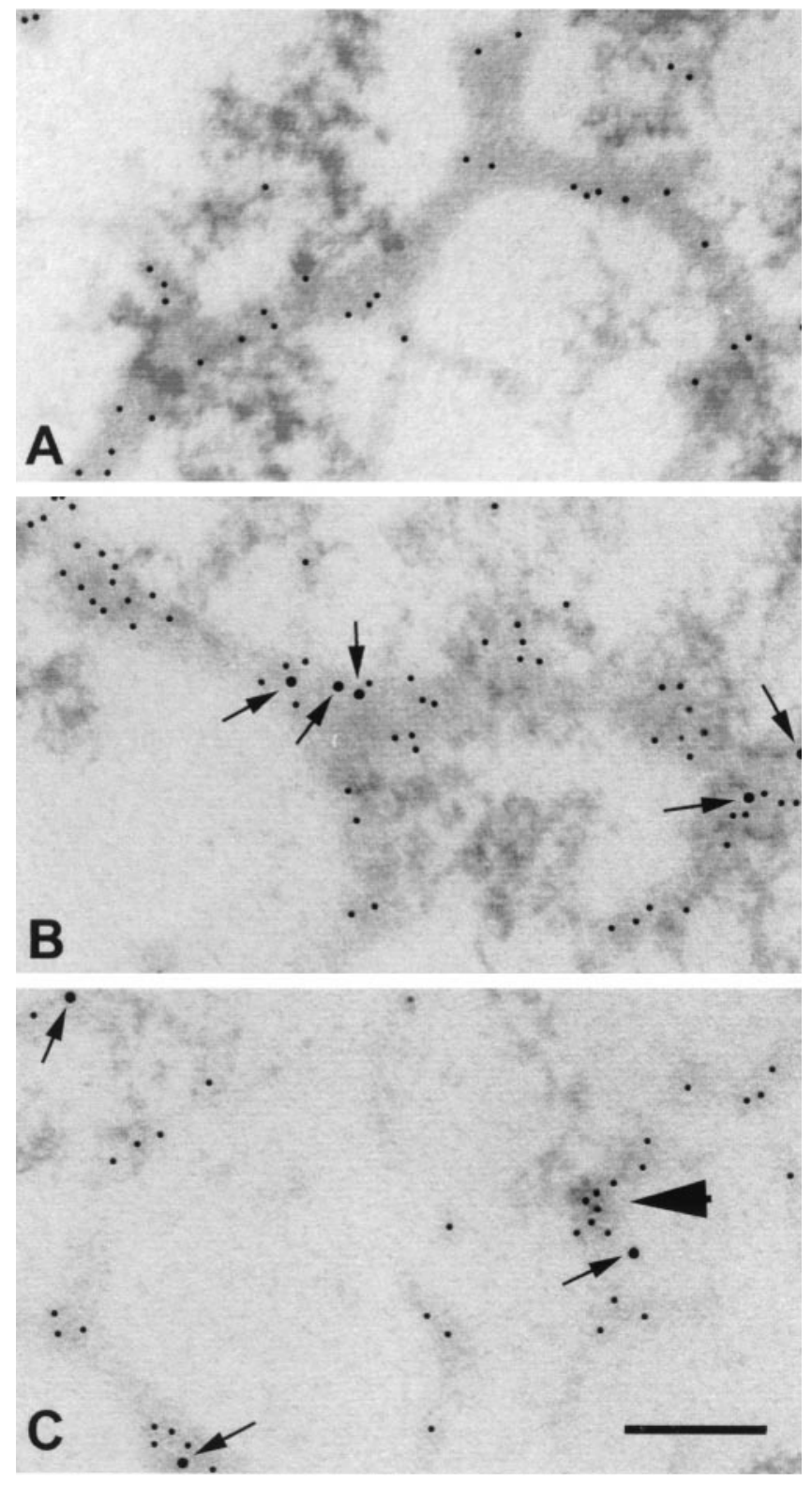

Figure 2. Double immunogold labeling of internalized hsp27 antibody and actin in human retina. $A$, Immunoelectron microscopy of control retina incubated in the absence of hsp27 antibody exhibited actin antibody-labeled microfilaments in retinal ganglion cells $(5 \mathrm{~nm}$ gold particles). $B$, After incubation of retinas with hsp27 antibody for $6 \mathrm{hr}$, immunoelectron microscopy revealed colocalization of hsp27 antibody (10 $\mathrm{nm}$ gold particles) with actin (5 nm gold particles). Notice the close proximity of hsp27 antibody (arrows) with actin-labeled areas in the human retina. $C$, In retinas incubated with hsp27 antibody for $12 \mathrm{hr}$, actin microfilaments disappeared in some of the ganglion cells, leaving irregular actin aggregations (arrowhead). Scale bar, $0.25 \mu \mathrm{m}$.

taining one or more dense nuclear fragments. Apoptosis was virtually absent in control grids from human retina incubated either with anti-IgG or anti-calbindin-D as control antibodies or without any antibody. At least five grids from human retina, each containing approximately 50 retinal ganglion cells, were examined in a masked fashion for each time point of incubation during three identical experiments. Ultrastructural features compatible with apoptosis were detected in $\sim 2 \%$ of ganglion cells in retinas incubated with hsp27 antibody, whereas apoptosis was seen in
$<0.1 \%$ of the cells in control retinas incubated either with control antibodies or without antibody. In addition, electron microscopy revealed that scattered neuronal cells in the inner and outer nuclear layers also exhibited morphological characteristics consistent with apoptotic cell death. We estimated that although apoptosis was virtually absent in control retinas, it was present in $<1 \%$ of the neuronal cells other than ganglion cells in retinas incubated with hsp27 antibody.

The TUNEL technique in conjunction with the fluorescence microscopy showed brightly fluorescein-stained nuclei representing fragmented DNA in human retina incubated with hsp27 antibody. TUNEL positivity was localized to retinal cells exhibiting positive immunolabeling for neuron-specific enolase or neurofilament protein. The positive TUNEL was detected in $2.6 \%$ of the total number of ganglion cells in human retina incubated with hsp27 antibody for $12 \mathrm{hr}$, whereas the number of TUNELpositive ganglion cells was $0.09 \%$ in control retinas (Fig. $3 F, G$ ). The positive TUNEL was detected in 0.06 and $0.05 \%$ of neuronal cells located in the inner or outer nuclear layers of the control retinas, respectively. However, the TUNEL was positive in $0.6 \%$ of neuronal cells in the inner nuclear and $0.4 \%$ of the neuronal cells in the outer nuclear layers of retinas incubated with hsp27 antibody for $12 \mathrm{hr}$.

To better estimate the overall occurrence of apoptotic cell death, a rat retinal cell line was grown in culture and incubated in the presence of hsp27 antibody. As presented previously, the retinal cells in this cell line can internalize hsp27 antibody as assessed by fluorescence microscopy (Tezel et al., 1998). Double immunolabeling revealed that hsp27 antibody internalization was observed in all cells. However, the TUNEL was positive in $\sim 30 \%$ of the cell population that was simultaneously counterstained with only neuronal markers. With the exception of cells that exhibited positive TUNEL caused by engulfed apoptotic bodies, the TUNEL was not positive in cells counterstained with only glial markers (Tezel et al., 1998). These data are similar to our current observations using human retina and provide information that the induction of apoptosis in this cell line is specific to neurons. However, the lack of fully differentiated retinal cell phenotypes in these cultures limits the quantitation of neuronal cell subtypes undergoing apoptosis.

The cultured rat retinal cells (Seigel, 1996) were incubated with hsp27 antibody and examined by flow cytometry using fluorescein labeling to detect DNA breaks (Fig. 4). Although $2 \%$ of control cells demonstrated a fluorescence intensity above $10^{1}$ after fluorescein labeling of DNA breaks (Fig. $4 A$ ), the same fluorescence intensity occurred in as much as $44 \%$ of the cell population incubated with hsp27 antibody for $24 \mathrm{hr}$ (Fig. 4C). However, in retinal cells incubated with control antibody, the percentage of cells demonstrating a fluorescence intensity above $10^{1}$ (Fig. $4 B$ ) was similar to control cells that were incubated without antibody (3\%). The results of flow cytometric analysis of cultured retinal cells were in agreement with estimates of apoptosis obtained by morphological assessment.

Western blot analysis using retinal cell lysates demonstrated that incubation with hsp27 antibody caused a cleavage of caspase- 8 and caspase- 3 . Western blots revealed the presence of a $17 \mathrm{kDa}$ subunit derived from the cleavage of $32 \mathrm{kDa}$ pro-enzyme caspase-3 and $\sim 30$ and $20 \mathrm{kDa}$ cleaved products of $55 \mathrm{kDa}$ immunoreactive band corresponding to pro-caspase- 8 (Fig. 5). Incubation of the retinal cells with hsp 27 antibody in the presence of drugs inhibiting caspases prevented specific caspase cleavage. The membrane-permeable, nonselective caspase inhibitor B-D- 

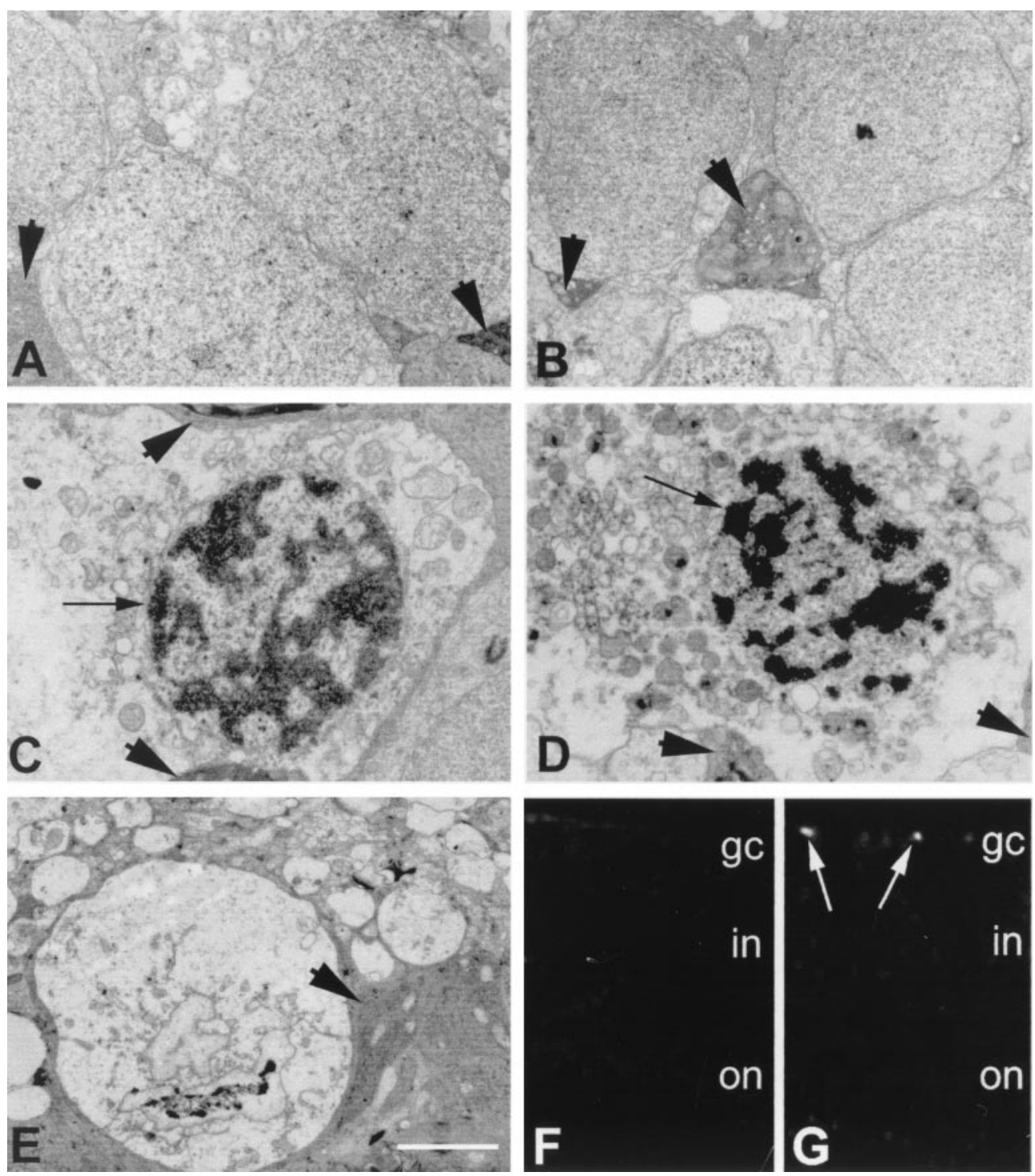

Figure 3. Evidence of apoptosis in human retina incubated with hsp27 antibody. A, Electron micrograph of normal-appearing ganglion cells in human retina incubated without antibody. $B$, Electron micrograph of normal-appearing ganglion cells in human retina incubated with control antibody. Ganglion cells are sheathed by electron-dense glial processes (arrowheads) that originate from Müller cells characterized by dark cytoplasm containing different organelles and parallel filaments. Ganglion cells in human retina incubated with hsp27 antibody for $6 \mathrm{hr}(C)$ or $12 \mathrm{hr}(D)$ illustrated abnormal nuclear morphology. Black arrows show nuclei with clumped dense chromatin in cells with condensed cytoplasm and intact cytoplasmic organelles. E, An apoptotic body with a dense clump of presumed chromatin. Cytoplasmic organelles and surrounding membranes, however, are still intact. Scale bar: $A-E$, $2 \mu \mathrm{m} . F, G$, Fluorescence microscopy images (original magnification 40×) using TUNEL technique in control retina incubated without antibody and retina incubated with hsp27 antibody, respectively. The TUNEL technique showed brightly fluorescein-stained nuclei representing fragmented DNA in human retina incubated with hsp27 antibody (white arrows).

FMK (50 $\mu \mathrm{M})$ (Thornberry et al., 1992; Graybill et al., 1994; Boudreau et al., 1995) inhibited caspase-3 cleavage but did not result in a prominent change in caspase- 8 cleavage, whereas Z-IETD-FMK (20 $\mu \mathrm{M}$ ), a specific caspase-8 inhibitor (Mashima et al., 1995a), inhibited the cleavage of caspase- 8 and only partly inhibited the cleavage of caspase- 3 .

In addition to Western blotting, caspase-3-like activity was measured by fluorometric assay and was increased approximately five times in cultured retinal cells incubated with hsp27 antibody $(22.10 \pm 3.9 \mathrm{pmol} / \mathrm{mg}$ protein per minute) compared with control cells $(4.00 \pm 1.1 \mathrm{pmol} / \mathrm{mg}$ protein per minute). The caspase-3-like activity in retinal cells incubated with hsp27 antibody was reduced $\sim 70 \%$ with $50 \mu \mathrm{M}$ B-D-FMK $(6.42 \pm 1.1 \mathrm{pmol} / \mathrm{mg}$ protein per minute) and $40 \%$ with $20 \mu \mathrm{M}$ Z-IETD-FMK (12.64 \pm 1.9 $\mathrm{pmol} / \mathrm{mg}$ protein per minute).

\section{Receptor identification and regulation of hsp27 antibody endocytosis}

We sought to learn whether apoptosis induced by hsp27 antibody was dependent on the presence or activation of complement. Therefore we performed experiments in which cultured retinal cells were incubated in the presence of heat-inactivated serum as a substitute for conventional serum. The use of heat-inactivated serum did not change the rate of apoptosis induced by hsp27 antibody in retinal cells (Fig. 4D).

To assess whether internalization of hsp27 antibody by retinal 


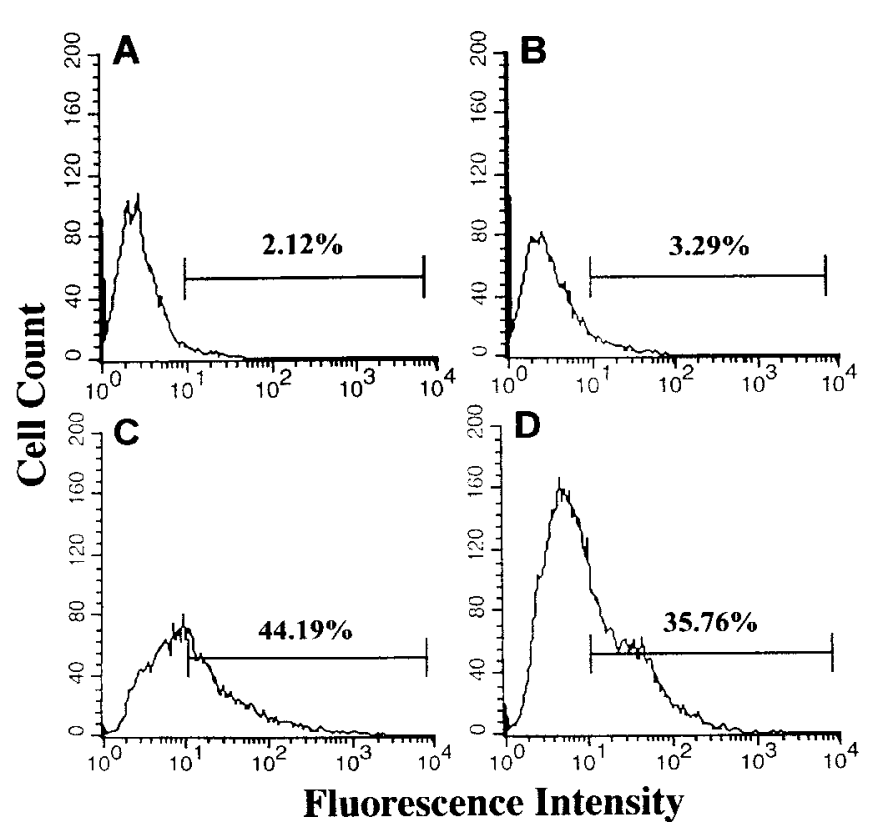

Figure 4. Flow cytometric analysis of apoptotic cell death in E1A.NR3 rat retinal cells. Histograms obtained after fluorescein staining of DNA breaks are shown in control cells incubated without hsp27 antibody $(A)$, in cells incubated with anti-IgG control antibody $(B)$, in cells incubated with hsp27 antibody $(C)$, or in cells incubated with hsp27 antibody in the presence of heat-inactivated serum $(D)$. There was no difference between apoptosis rates of the control cells incubated without hsp27 antibody and cells incubated with control antibody (Fisher's exact test, $p=0.65$ ). However, although 2-3\% of control cells demonstrated a fluorescence intensity above $10^{1}$, the same fluorescence intensity occurred in as much as $44 \%$ of the cell population incubated with hsp 27 antibody (Fisher's exact test, $p<0.0001$ ). The use of heat-inactivated serum did not markedly change the rate of apoptosis induced by hsp27 antibody (Fisher's exact test, $p=0.25$ ). Data are representative of three independent experiments that were collected using logarithmic amplification of at least 10,000 cells.

cells is dependent on binding to hsp27 recognition sites on the cell surface, we performed competition experiments in which the isolated human retina or cultured retinal cells were preincubated with recombinant human hsp27. Immunoelectron microscopy performed in a masked fashion revealed that the internalization of hsp27 antibody and induction of apoptosis were reduced in human retina preincubated with hsp27 (Fig. $6 A--C$ ). The number of gold particles bound to hsp 27 antibody observed inside the human retinal cells was $\sim 50 \%$ less in retinas preincubated with hsp27 compared with retinas incubated with hsp27 antibody without a preincubation with hsp27. Flow cytometric analysis of cultured rat retinal cells also revealed that preincubation with purified hsp27 resulted in a dose-dependent decrease in the rate of DNA fragmentation induced by hsp27 antibody (Fig. 6E). These observations may suggest a facilitating role of external binding sites of hsp27 for the internalization of hsp27 antibody in retinal cells.

To assess whether Fc receptor occupancy is essential for endocytosis of hsp27 antibody, we performed experiments that revealed that Fc receptor blockade with Fc fragments of IgG did not appreciably effect the internalization of hsp 27 antibody by retinal neuronal cells (Fig. 6D).

Caspase- 8 activation during the execution of apoptotic cell death induced by exogenous hsp 27 antibody also prompted us to
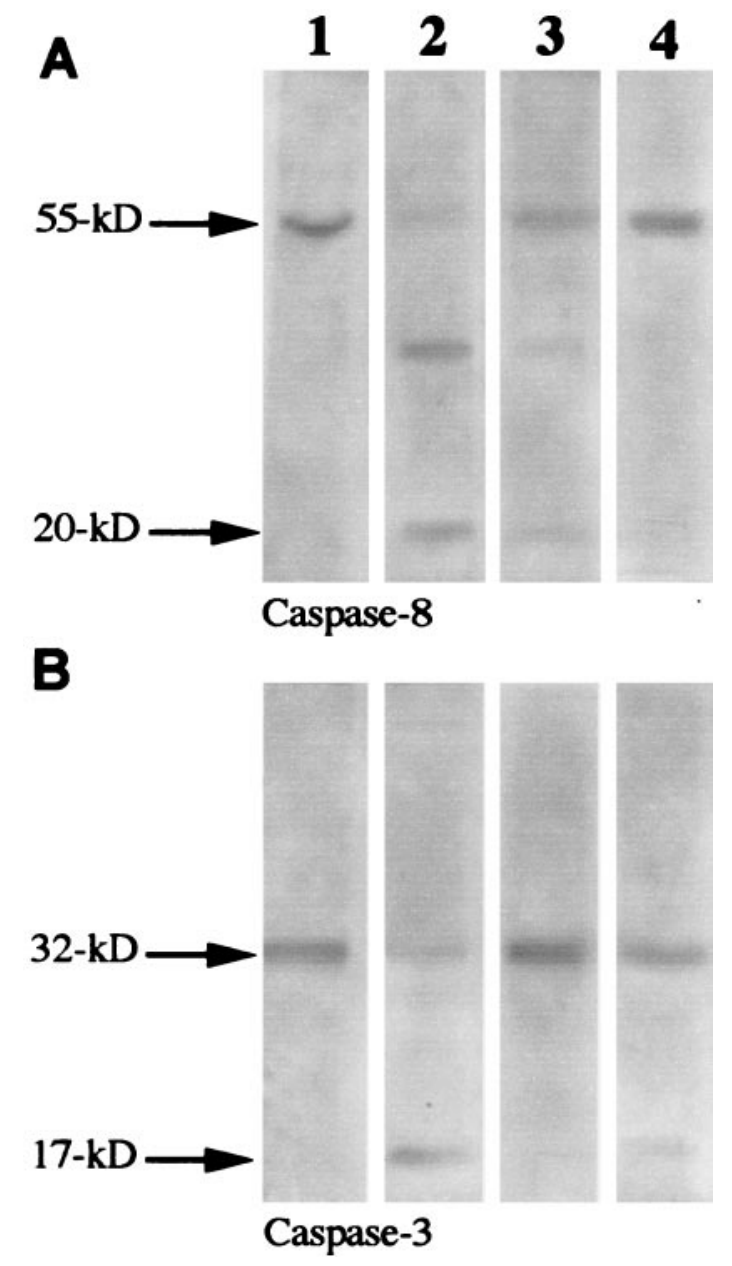

Figure 5. Western blot findings demonstrating caspase cleavage: column 1, control retinal cells (E1A.NR3); column 2, retinal cells incubated with hsp27 antibody $(100 \mu \mathrm{g} / \mathrm{ml})$ for $24 \mathrm{hr}$; column 3, retinal cells incubated with hsp27 antibody in the presence of a nonselective caspase inhibitor, B-D-FMK $(50 \mu \mathrm{M})$; column 4, retinal cells incubated with hsp27 antibody in the presence of the caspase-8 inhibitor Z-IETD-FMK $(20 \mu \mathrm{M})$. Although no cleavage of caspase-8 $(A$, column 1$)$ or caspase-3 ( $B$, column 1 ) was detected using the lysates of the control retinal cells, cleavage of caspase- 8 and caspase- 3 was observed using retinal cells incubated with hsp27 antibody. A $55 \mathrm{kDa}$ immunoreactive band corresponding to caspase- 8 cleaved to 30 and $20 \mathrm{kDa}$ products is shown in $A$, column $B$. A $32 \mathrm{kDa}$ pro-enzyme caspase- 3 cleaved to a $17 \mathrm{kDa}$ subunit is shown in $B$, column 2. Incubation of the retinal cells with hsp27 antibody in the presence of caspase inhibitors prevented specific caspase cleavage. B-DFMK effectively inhibited caspase- 3 and partially prevented caspase- 8 cleavage (column 3); Z-IETD-FMK inhibited the cleavage of caspase-8 and only partially inhibited the cleavage of caspase-3 (column 4).

determine whether the TNF family of receptors may be involved (Muzio et al., 1996) in the internalization of hsp27 antibody or the initiation of hsp27-related apoptosis. However, there was no noticeable difference in the internalization of hsp27 antibody or in the induction of apoptosis in P-55- or P-75-knockout or lpr mice compared with controls by immunoelectron microscopy (data not shown). This suggests that the TNF family of receptors does not mediate the internalization of hsp 27 antibody by retinal cells.

\section{Hsp27 antibody degrades actin cytoskeleton}

The degradation of actin after hsp27 antibody incubation was confirmed by flow cytometric analysis of cultured retinal cells. 

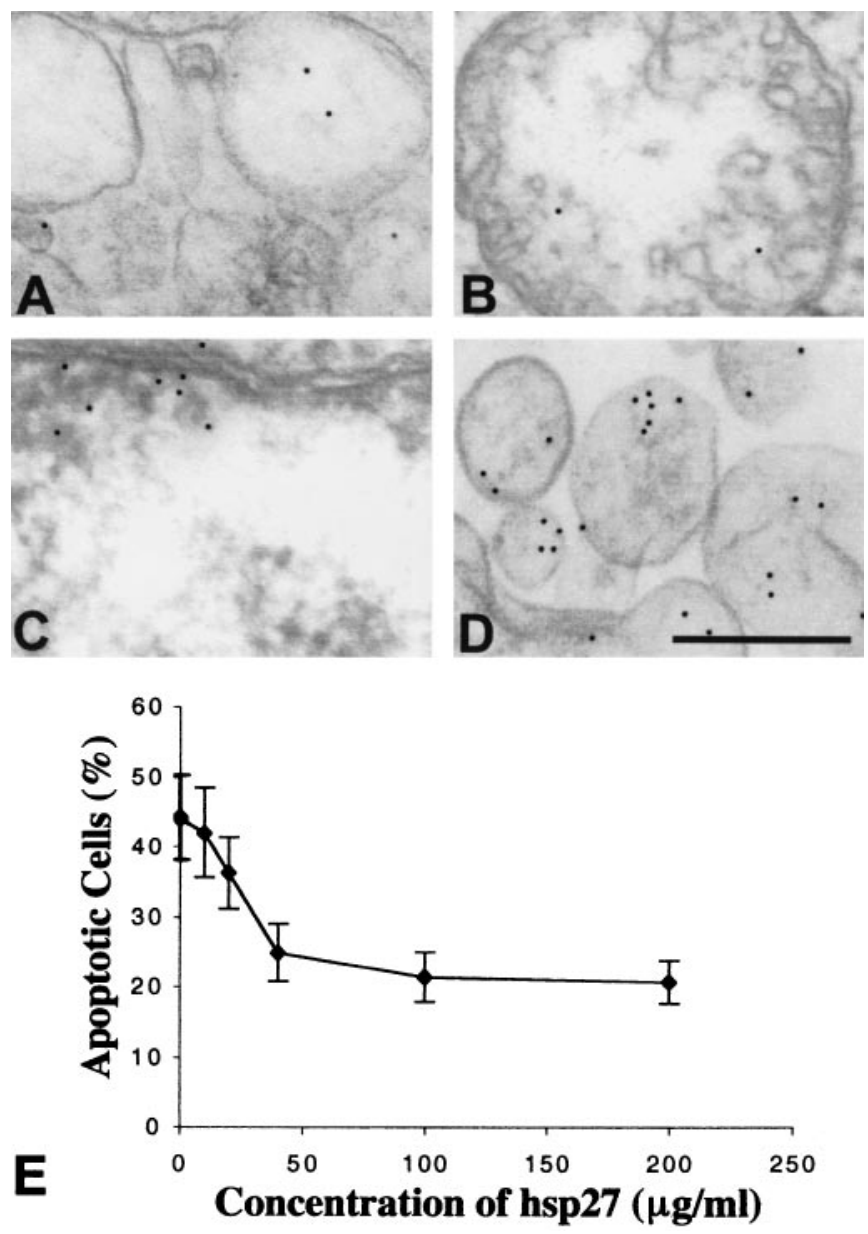

Figure 6. Regulation of hsp27 antibody internalization in retinal cells. Decreased internalization of hsp27 antibody in human retinal ganglion cells preincubated with purified hsp27 is shown. Approximately 50\% decreased numbers of gold particles in vesicular structures $(A)$, in a mitochondrion $(B)$, and in the nucleus $(C)$ are shown. Fc receptor blockade with $\mathrm{Fc}$ fragments of $\mathrm{IgG}$ did not change the internalization of hsp27 antibody by retinal neuronal cells $(D)$. Scale bar, $0.5 \mu \mathrm{m}$. Flow cytometric analysis of cultured retinal cells preincubated with purified hsp27 revealed that the percentage of cells having fluorescein-labeled DNA fragments after incubation with hsp27 antibody decreased in a dose-dependent manner $(E)$. The percentage of cells exhibiting a fluorescence intensity above $10^{1}$ was obtained from fluorescence histograms and used to generate the graphic. Data are representative of three independent experiments that were collected using logarithmic amplification of at least 10,000 cells.

Retinal cells incubated with hsp27 antibody for 6 or $12 \mathrm{hr}$ demonstrated a decrease in the relative F-actin (polymeric actin) content as assessed by the mode of phalloidin fluorescence on the fluorescence histograms. A shift in the population distribution of the phalloidin-stained cells is shown in Figure 7 after incubation with hsp27 antibody. The depolymerization of actin, which was assessed by an increase in the shifted peak of fluorescence below $10^{1}$, was dependent on the concentration of hsp27 antibody. We also observed a concurrent increase in G-actin (monomeric actin) in these cells using Dnase staining.

Western blotting further demonstrated that incubation of cultured retinal cells with hsp27 antibody resulted in cleavage of 42 $\mathrm{kDa}$ actin (G-actin) to $\sim 30$ and $10 \mathrm{kDa}$ fragments. In addition, incubation of retinal cells with hsp27 antibody in the presence of a nonselective caspase inhibitor, B-D-FMK, decreased actin cleavage. This suggests a role of caspase activation in the proteolytic cleavage of actin seen in retinal cells incubated with hsp27 antibody (Fig. 7I).

In addition, electron microscopic examination of human retina revealed a marked shortening and disorganization of actin microfilaments in human retinal cells incubated with hsp27 antibody (Fig. 2C).

\section{DISCUSSION}

\section{Internalization of hsp27 antibody by retinal cells}

Exogenous hsp27 antibody can enter retinal cells and lead to subsequent apoptotic cell death. Electron microscopy findings, including the time-dependent appearance of gold particles in coated pits and vesicular structures, suggests that internalization of hsp27 antibody occurs via classic receptor-mediated endocytosis (Schmid, 1992; Jans, 1994; Mukherjee et al., 1997). During endocytosis hsp27 antibody is bound to cell surface sites and later to intracellular compartments, including mitochondria and nuclei, that correspond to the loci at which native intracellular hsp27 has been identified (Beaulieu et al., 1989; Mehlen and Arrigo, 1994).

\section{Induction of apoptosis}

Apoptotic cell death is a sequel of hsp27 antibody endocytosis in both human retina and the cultured rat retinal cell line. The internalization of hsp27 antibody activates a proteolytic cascade, which includes caspase- 8 and caspase- 3 activation and the cleavage of poly-(ADP ribose) polymerase (Tezel and Wax, 1999). The induction of apoptosis in retinal cells after internalization of hsp27 antibody is likely caused by antibody binding, which confers a loss of protective function of native hsp27. Hsp27 functions as a chaperone and increases cell survival and resistance to apoptosis by affecting both upstream signaling and downstream effector events in different cell lines, including neuronal cells (Kato et al., 1995; Mehlen et al., 1996; Samali and Cotter, 1996; Guénal et al., 1997a; Wagstaff et al., 1999). The most prominent loss of retinal neurons by hsp27 antibody-mediated apoptosis occurred in the ganglion cell layer, suggesting that hsp27 plays a particularly important role in this cell layer. In addition, because retinal ganglion cells are axotomized in the ex vivo and in vitro models we used, it is tempting to speculate that this may increase their susceptibility to apoptotic cell death.

The different rates of apoptotic cell death that we observed in ex vivo and in vitro studies might be related to the different incubation time with hsp27 antibody used in each model. Although the incubation time was as long as $12 \mathrm{hr}$ in experiments using human retina, incubation time was $24 \mathrm{hr}$ in experiments using cultured retinal cells. In addition, unlike adult neurons in human retina, retinal cells in our immortalized cultures are mitotic. This may account for an increase in the number of cells exposed to hsp27 antibody in cultures during the incubation period. The multilayered nature of the cells within isolated human retina might also decrease the access of antibody compared with monolayered retinal cell cultures. Furthermore, the cultured retinal cells used in our studies exhibit features of retinal precursor cells, rather than mature retinal phenotype. This may also be important for the increased rate of apoptosis in our in vitro experiments.

In vitro studies demonstrate that antisense inhibition of hsp27 affects cell growth and several cellular functions (Mairesse et al., 1996). Antibodies that bind heat shock proteins have been shown to increase the rate of cell death after certain noxious insults (Riabowol et al., 1988). For example, autoantibodies to hsp60 

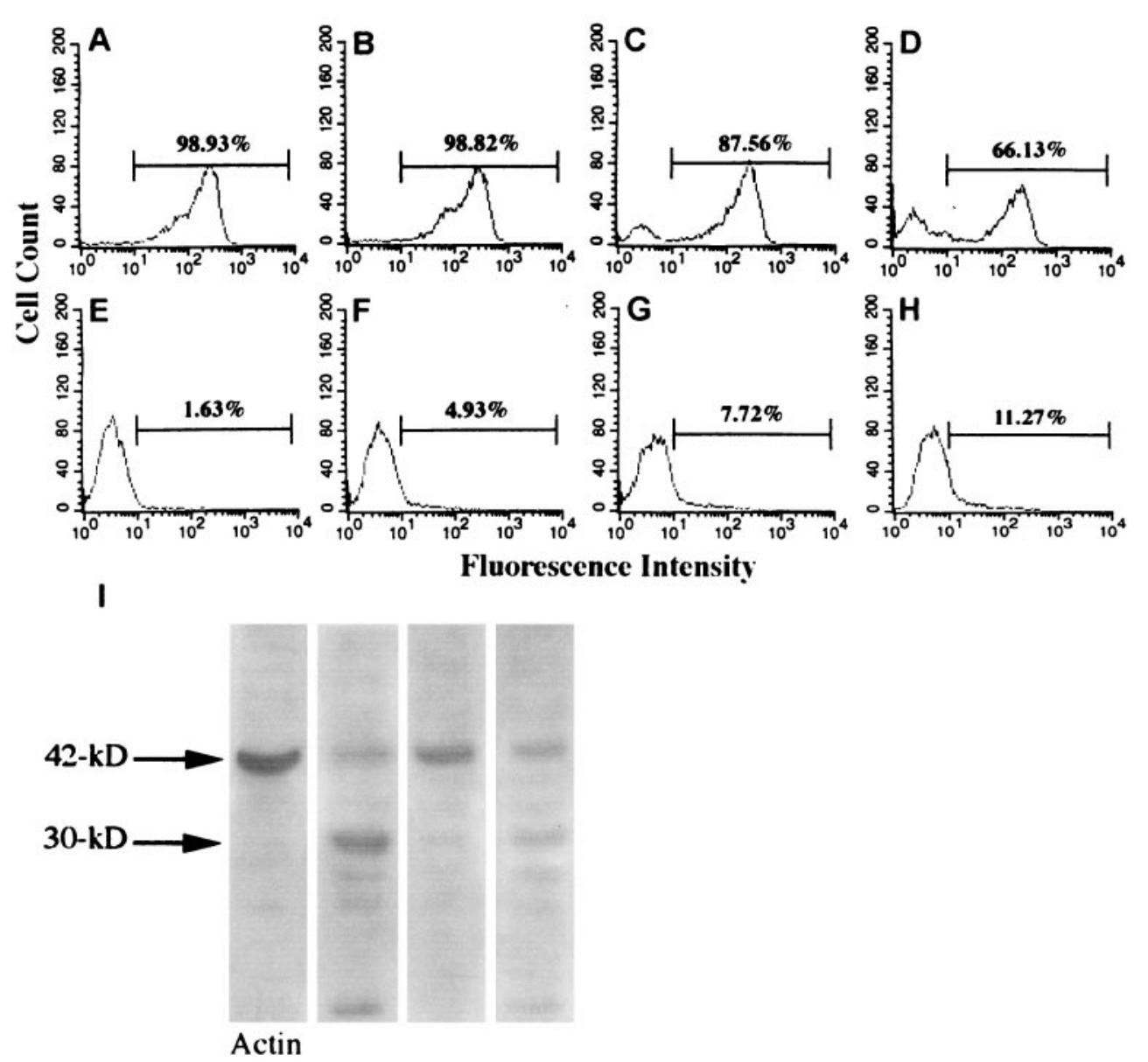

Figure 7. Flow cytometric analysis of F- and G-actin in retinal cells incubated with hsp27 antibody. F- and G-actin in retinal cells were examined by double staining using phalloidin and Dnase I. $A, B, C$, and $D$ represent fluorescein isothiocyanate fluorescence intensity of phalloidin staining, and $E$, $F, G$, and $H$ represent Texas Red fluorescence intensity of Dnase I staining. $A, E$, Control cells; $B, F$, retinal cells incubated with $50 \mu \mathrm{g} / \mathrm{ml} ; C$, $G, 100$ $\mu \mathrm{g} / \mathrm{ml}$ of hsp27 antibody; $D, H, 200 \mu \mathrm{g} / \mathrm{ml}$ of hsp27 antibody. A shift in the population distribution of the phalloidin-stained cells, which corresponds to depolymerization of actin, was dependent on the concentration of hsp27 antibody. Although $99 \%$ of control cells demonstrated a fluorescence intensity above $10^{1}$, the same fluorescence intensity occurred in only $66 \%$ of the cell population incubated with $200 \mu \mathrm{g} / \mathrm{ml}$ of hsp27 antibody and exhibited a second peak below $10^{1}$ (Fisher's exact test, $p<0.0001$ ). There was a concurrent increase in G-actin in these cells as assessed by Dnase I staining (Fisher's exact test, $p=0.01$ ). Data are representative of three separate experiments. $I$, In addition, Western blot analysis revealed a proteolytic cleavage of actin in retinal cells incubated with hsp27 antibody. I, Column 1, control retinal cells (E1A.NR3); column 2, retinal cells incubated with hsp27 antibody (100 $\mu \mathrm{g} / \mathrm{ml}$ ) for $24 \mathrm{hr}$; column 3, retinal cells incubated with hsp27 antibody in the presence of a nonselective caspase inhibitor, B-D-FMK (50 $\mu \mathrm{M})$; column 4 , retinal cells incubated with hsp27 antibody in the presence of the caspase-8 inhibitor Z-IETD-FMK $(20 \mu \mathrm{M})$. In retinal cells incubated with hsp27 antibody, $42 \mathrm{kDa}$ actin (G-actin) (column 1) cleaved to $\sim 30$ and $10 \mathrm{kDa}$ fragments (column 2). Simultaneous incubation with B-D-FMK inhibited the cleavage of actin in retinal cells after incubation with hsp27 antibody (column 3$)$.

have been found to mediate endothelial toxicity in human vasculature (Schett et al., 1995). Furthermore, hsp27 antibody can adversely affect some intracellular functions as shown by incubation of mouse smooth muscle cells with hsp27 antibody, which prevents bombesin and kinase-C-induced sustained contractions (Bitar et al., 1991). Thus, antibody binding to intracellular hsp27 may inactivate or attenuate the protective function of hsp27 in these cells by interfering with the structural organization, oligomerization, or phosphorylation of hsp27, which are thought to be central to its function (Lavoie et al., 1995; Mehlen et al., 1997). We propose that this apoptotic sequence may underlie the glaucomatous optic neuropathy that occurs in patients who have elevated titers of serum antibodies to hsp27 (Tezel et al., 1998).

\section{Receptor identification and regulation of hsp27 antibody endocytosis}

We examined the possibility that external binding sites for hsp27 could facilitate internalization of hsp27 antibody and found that internalization of hsp27 antibody could be partly prevented by hsp27 competition. This finding suggests the presence of specific Fab recognition sites for heat shock proteins on plasma membrane. Studies of the effects of exogenous heat shock proteins on promonocytes have demonstrated that exogenous heat shock proteins may modulate vital cellular functions and protect cells against cytotoxic factors after binding to the cell surface and internalizing (Guzhova et al., 1998). The well known transfer of heat shock proteins from glial to neuronal cells similarly suggests external binding sites of heat shock proteins and subsequent internalization (Tytell et al., 1986; Hightower and Guidon, 1989; Sheller et al., 1998). In addition, high serum titers of autoantibodies to nonbacterial human heat shock proteins in autoimmune diseases (Multhoff and Hightower, 1996) further support the hypothesis that the induction of the immune response requires external binding sites of heat shock proteins.

Although peptide competition using preincubation with puri- 
fied hsp27 1 hr before the hsp27 antibody incubation decreased apoptosis rates, we are unable to differentiate whether the purified hsp 27 bound to hsp27 antibody in the medium decreased subsequent cellular binding of hsp27 antibody or whether it blocked the external binding sites for hsp27 antibody in retinal cells.

We surmised that internalization of hsp27 antibody in retinal cells may also be mediated by Fc $\gamma$ receptors that recognize the Fc domain of immunoglobulin molecules (Alarcon-Segovia et al., 1978) because Fc $\gamma$ receptors on macrophage and lymphocyte membranes mediate phagocytosis by a process including internalization and lysosomal degradation (Mellman et al., 1983; Lowry et al., 1998). In addition, retinal microglial cells express MHC molecules constitutively (Schnitzer and Scherer, 1990; Provis et al., 1995), and binding and internalization of IgG occurs in cultured retinal cells (Adamus et al., 1997) as well as in vascular endothelial cells (Ronda et al., 1997).

We therefore performed experiments in which isolated human retina was incubated with $\mathrm{Fc}$ fragments from human $\mathrm{IgG}$ before the incubation with hsp27 antibody or control antibody. The experiments revealed that Fc receptor blockade was not effective in blocking hsp27 antibody internalization by neuronal cells. Thus, interaction with $\mathrm{Fc}$ receptors is not the mechanism by which the internalization of hsp27 antibody occurs in retinal neurons.

Using deficient mice for either TNF- $\alpha$ or fas receptors, we could not detect any evidence that this family of receptors is involved in the internalization of hsp 27 antibody by retinal cells. An alternate mechanism for caspase- 8 activation in the retina might be the presence of immobilized antigen-antibody complexes that are bound to Fc receptors, because these have been found to be a stimulus for TNF- $\alpha$ generation (Kim et al., 1991). Therefore, although TNF receptors do not mediate internalization of hsp27 antibody, receptor binding by hsp27 antibody may contribute to an increased secretion of TNF- $\alpha$ and result in activation of caspase- 8 via TNF receptor occupancy. In addition, hsp27 counteracts TNF- $\alpha$-mediated disruption of actin architecture and enhances cellular resistance to TNF- $\alpha$-mediated apoptotic cell death (Mehlen et al., 1996a,b). Therefore the decreased protective function of hsp 27 caused by antibody binding may render retinal cells more sensitive to induction of apoptosis mediated by TNF- $\alpha$ via caspase- 8 activation. The possibility that caspase- 8 may be activated by mechanisms unrelated to TNF- $\alpha$ receptor binding (Slee et al., 1999) cannot be excluded.

\section{Effects of hsp27 antibody on actin dynamics}

Induction of apoptosis by microfilament disruption with cytochalasin B (Kolber et al., 1990) or by actin depolymerization with bis(tri-n-butyltin) oxide (Raffray and Cohen, 1991) or thymosine $\beta 10$ (Hall, 1995) indicates that cytoskeletal breakdown may be one of the key events for the initiation of apoptosis. Cytoskeletal degradation has indeed been identified as an early event during the apoptotic process (Tsukidate et al., 1993; Bonfoco et al., 1995; Levee et al., 1996; Guénal et al., 1997b; van Engeland et al., 1997). In addition to the structural functions of actin cytoskeleton, which are critical for cell survival, actin is a natural inhibitor of the endonucleolytic activity of Dnase I (Lazarides and Lindberg, 1974; Kayalar et al., 1996). Degradation of actin may therefore result in both a markedly decreased ability of actin to inhibit the endonucleolytic activity of Dnase I and a diminished ability of actin to polymerize (Kayalar et al., 1996).

We observed increased degradation of actin cytoskeleton in retinal cells incubated with hsp27 antibody that was characterized by both actin depolymerization and protein cleavage. Because hsp27 serves as a chaperone to stabilize the cytoskeleton (Welch and Suhan, 1985; Gabai and Kabakov, 1993; Jakob et al., 1993; Lavoie et al., 1993, 1995; Huot et al., 1996), hsp27 antibody may confer a loss of this function and account for cytoskeletal breakdown as a key event for the apoptotic cell death in these cells. The colocalization of internalized hsp27 antibody with actin cytoskeleton in human retinal cells supports the effect of hsp27 antibody at the level of hsp27 and cytoskeleton interaction.

Proteolytic cleavage of actin by caspases has been proposed to have a role in the specific and sequential changes of the actin cytoskeleton or different regulators of the microfilament system during the apoptotic process (Martin and Green, 1995; Mashima et al., 1995b; Brancolini et al., 1997; Martin et al., 1998). Our observations in which the inhibition of caspases decreased actin cleavage indicate a role of the proteolysis cascade in actin degradation during hsp27 antibody-related apoptosis. Previous observations suggest that proteolytic cleavage of actin occurs only when actin is unpolymerized. Therefore, polymerized actin is resistant to degradation in whole cells (Welch and Suhan, 1985; Song et al., 1997). Although actin contains cleavage sites for ICE-like proteases (Mashima et al., 1995), it is not degraded in vivo in human cells because of either lack of access of these proteases to actin or other factors that prevent degradation (Song et al., 1997). Therefore, we propose that depolymerization of actin in retinal cells incubated with hsp27 antibody renders actin sensitive to further degradation. Alternatively, however, actin degradation may result from several other proteolytic processes (Villa et al., 1998) or by mechanisms other than proteolysis, such as (hyper)phosphorylation of actin-associated proteins (Wickstrom et al., 1995) or glutathione depletion (Scanlon et al., 1989; Kim et al., 1991). Some of these mechanisms, which are also relevant to hsp27 biochemistry, may further contribute to hsp27 antibody-mediated apoptosis.

\section{Possible implications}

Although heat shock proteins initially serve to protect cells from further destruction and facilitate repair, their enhanced expression in several diseases may consequently render them as immune targets involved in the progression of disease (Young, 1992; Aquino et al., 1997). An activated immune response, such as increased autoantibodies to hsp27 found in many patients with glaucoma (Tezel et al., 1998) or cancer (Conroy et al., 1998), may therefore represent a generalized response to tissue stress and/or damage that subsequently contributes to disease progression by diminishing the protective abilities of native hsp27. Thus, our observations may have significance beyond retinal neurodegenerative diseases such as glaucoma. For example, hsp27 preparations derived from surgically resected tumors might be used to induce tumor-specific immunity (Poccia et al., 1992; Srivastava, 1994; Piselli et al., 1995) in which generated autoantibodies directed to hsp27 (Hitotsumatsu et al., 1996; Assimakopoulou et al., 1997; Morino et al., 1997; Jaattela, 1999) can enter cancer cells and trigger apoptosis. Poor prognosis in cancer patients whose tumors have increased expression of hsp27 (Hitotsumatsu et al., 1996; Assimakopoulou et al., 1997) and improved survival rates in patients with breast cancer who have serum antibodies to hsp27 (Conroy et al., 1998) support the feasibility of this suggestion.

In conclusion, our observations provide novel evidence for internalization of exogenously applied hsp 27 antibody by retinal cells. We conclude that internalization of hsp27 antibody results 
in a decreased ability of endogenous hsp27 to stabilize actin cytoskeleton, thereby facilitating apoptotic cell death. The possibility that the protective function of native hsp27 can be modulated by antibodies to hsp27 thus provides a rationale for novel immune-based strategies to modulate apoptotic cell death in selected diseases.

\section{REFERENCES}

Adamus G, Machnicki M, Seigel GM (1997) Apoptotic retinal cell death induced by autoantibodies of cancer-associated retinopathy. Invest Ophthalmol Vis Sci 38:283-291.

Alarcon-Segovia D, Lorente L (1983) Antibody penetration into living cells IV. Different effects of anti-native DNA and antiribonucleoprotein IgG on the cell cycle of activated T cells. Clin Exp Immunol 52:365-371.

Alarcon-Segovia D, Ruiz-Argüelles A, Fishbein E (1978) Antibody to nuclear ribonucleoprotein penetrates live human mononuclear cells through Fc receptors. Nature 271:67-69.

Alarcon-Segovia D, Ruiz-Argüelles A, Lorente L (1996) Broken dogma: penetration of autoantibodies into living cells. Immunol Today 17:163-164.

Aquino DA, Capello E, Weisstein J, Sanders V, Lopez C, Tourtellotte WW, Brosnan CF, Raine CS, Norton WT (1997) Multiple sclerosis: altered expression of 70- and 27-kDa heat shock proteins in lesions and myelin. J Neuropathol Exp Neurol 56:664-672.

Assimakopoulou M, Sotiropoulou-Bonikou G, Maraziotis T, Varakis I (1997) Prognostic significance of Hsp-27 in astrocytic brain tumors: an immunohistochemical study. Anticancer Res 17:2677-2682.

Beaulieu JF, Arrigo AP, Tanguay RM (1989) Interaction of Drosophila $27000 M_{\mathrm{r}}$ heat-shock protein with the nucleus of heat-shocked and ecdysone-stimulated culture cells. J Cell Sci 92:29-36.

Bitar KN, Kaminski MS, Hailat N, Cease KB, Strahler JR (1991) Hsp27 is a mediator of sustained smooth muscle contraction in response to bombesin. Biochem Biophys Res Commun 181:1192-1200.

Bonfoco E, Ceccatelli S, Manzo L, Nicotera P (1995) Colchicine induces apoptosis in cerebellar granule cells. Exp Cell Res 218:189-200.

Boudreau N, Sympson CJ, Werb Z, Bissell MJ (1995) Supression of ICE and apoptosis in mammary epithelial cells by extracellular matrix. Science 267:891-893.

Brancolini C, Lazarevic D, Rodriguez J, Schneider C (1997) Dismantling cell-cell contacts during apoptosis is coupled to a caspasedependent proteolytic cleavage of $\beta$-catenin. J Cell Biol 139:759-771.

Bump NJ, Hackett M, Hugunin M, Seshagiri S, Brady K, Chen P, Ferenz C, Franklin S, Ghayur T, Li P, Licari P, Mankovich J, Shi L, Greenberg AH, Miller LK, Wong WW (1995) Inhibition of ICE family proteases by baculovirus antiapoptotic protein p35. Science 269:1885-1888.

Conroy SE, Sasieni PD, Amin V, Wang DY, Smith P, Fentiman IS, Latchman DS (1998) Antibodies to heat-shock protein 27 are associated with improved survival in patients with breast cancer. Br J Cancer 77:1875-1879.

Deshmukh M, Vasilakos J, Deckwerth TL, Lampe PA, Shivers BD, Johnson Jr EM (1996) Genetic and metabolic status of NGF-deprived sympathetic neurons saved by an inhibitor of ICE family proteases. J Cell Biol 135:1341-1354.

Dolzhanskiy A, Basch RS (1995) Flow cytometric determination of apoptosis in heterogeneous cell populations. J Immunol Methods 180:131-140.

Gabai VL, Kabakov AE (1993) Tumor cell resistance to energy deprivation and hyperthermia can be determined by the actin skeleton stability. Cancer Lett 70:25-31.

Graybill TL, Dolle RE, Helaszek CT, Miller RE, Ator MA (1994) Preparation and evaluation of peptidic aspartyl hemiacetala as reversible inhibitors of interleukin-1 $\beta$ converting enzyme (ICE). Int J Pept Protein Res 44:173-182.

Guénal I, Fraisse CS, Gaumer S, Mignotte B (1997a) Bcl-2 and hsp27 act at different levels to suppress programmed cell death. Oncogene 15:347-460.

Guénal I, Risler Y, Mignotte B (1997b) Down-regulation of actin genes precedes microfilament network disruption and actin cleavage during p53-mediated apoptosis. J Cell Sci 110:489-495.

Guzhova IV, Arnholdt AC, Darieva ZA, Kinev AV, Lasunskaia EB, Nilsson K, Bozhkov VM, Voronin AP, Margulis BA (1998) Effects of exogeneous stress protein 70 on the functional properties of human promonocytes through binding to cell surface and internalization. Cell Stress Chaperones 3:67-77.

Hall AK (1995) Thymosin beta-10 accelerates apoptosis. Cell Mol Biol Res 41:167-180.

Hanley T, Merlie JP (1991) Transgene detection in unpurified mouse tail DNA by polymerase chain reaction. Biotechniques 10:56.

Hightower LE, Guidon PT (1989) Selective release from cultured mammalian cells of heat-shock (stress) proteins that resemble glia-axon transfer proteins. J Cell Physiol 138:257-266.

Hitchcock SE (1980) Actin deoxyribonuclease I interaction. J Biol Chem 255:5668-5673.

Hitotsumatsu T, Iwaki T, Fukui M, Tateishi J (1996) Distinctive immunochemical profiles of small heat shock proteins (heat shock protein 27 and alpha B-crystallin) in human brain tumors. Cancer 77:352-361.

Hollander H, Makarov F, Dreher Z, van Driel D, Chan-Ling TL, Stone J (1991) Structure of the macroglia of the retina: sharing and division of labor between astrocytes and Müller cells. J Comp Neurol 313:587-603.

Howard TH, Meyer WM (1984) Chemotactic peptide modulation of actin assembly and locomotion in neutrophils. J Cell Biol 98:1265-1271.

Huot J, Houle F, Spitz DR, Landry J (1996) HSP27 phosphorylationmediated resistance against actin fragmentation and cell death induced by oxidative stress. Cancer Res 56:273-279.

Jaattela M (1999) Escaping cell death: survival proteins in cancer. Exp Cell Res 248:30-43.

Jakob U, Gaestel M, Engel K, Buchner J (1993) Small heat shock proteins are molecular chaperones. J Biol Chem 268:1517-1520.

Jans DA (1994) Nuclear signaling pathways for polypeptide ligands and their membrane receptors. FASEB J 8:841-847.

Kato H, Kogure K, Liu XH, Araki T, Kato K, Itoyama Y (1995) Immunohistochemical localization of the low molecular weight stress protein HSP27 following focal cerebral ischemia in the rat. Brain Res 679:1-7.

Kayalar C, Ord T, Testa MP, Zhong LT, Bredesen DB (1996) Cleavage of actin by interleukin $1 \beta$-converting enzyme to reverse DNase I inhibition. Proc Natl Acad Sci USA 93:2234-2238.

Kim JW, Wierda WG, Kim YB (1991) Immobilized IgG immune complex induces secretion of tumor necrosis factor-alpha by porcine alveolar macrophages. Am J Respir Cell Mol Biol 5:249-255.

Kolber MA, Broschat KO, Landa-Gonzales B (1990) Cytochalasin B induces cellular DNA fragmentation. FASEB J 12:3021-3027.

Lavoie JN, Hickey E, Weber LA, Landry J (1993) Induction of Chinese hamster hsp27 gene expression in mouse cells confers resistance to heat shock. Hsp27 stabilization of the microfilament organization. J Biol Chem 268:24210-24214.

Lavoie JN, Lambert H, Hickey E, Weber LA, Landry J (1995) Modulation of cellular thermoresistance and actin filament stability accompanies phosphorylation-induced changes in the oligomeric structure of heat shock protein 27. Mol Cell Biol 15:505-516.

Lazarides E, Lindberg U (1974) Actin is the naturally occurring inhibitor of Dnase I. Proc Natl Acad Sci USA 71:4742-4746.

Levee MG, Dabrowska MI, Lelli JL Jr, Hinshaw DB (1996) Actin polymerization and depolymerization during apoptosis in HL-60 cells. Am J Physiol 271:C1981-1992.

Lowry MB, Duchemin A, Robinson JM, Anderson CL (1998) Functional separation of pseudopod extension and particle internalization during Fc $\gamma$ receptor-mediated phagocytosis. J Exp Med 187:161-176.

Mairesse N, Horman S, Mosselmans R, Galand P (1996) Antisense inhibition of the $27 \mathrm{kDa}$ heat shock protein production affects growth rate and cytoskeletal organization in MCF-7 cells. Cell Biol Int 20:205-212.

Martin DA, Siegel RM, Zheng L, Lenardo MJ (1998) Membrane oligomerization and cleavage activates the caspase-8 (FLICE/MACH $\alpha 1$ ) death signal. J Biol Chem 273:4345-4349.

Martin SJ, Green DR (1995) Protease activation during apoptosis: death by a thousand cuts? Cell 82:349-352.

Mashima T, Naito M, Kataoka S, Kawai H, Tsuruo T (1995a) Aspartatebased inhibitor of interleukin-1 $\beta$-converting enzyme prevents antitumor agent-induced apoptosis in human myeloid leukemia U937 cells. Biochem Biophys Res Commun 209:907-915.

Mashima T, Naito M, Fujita N, Noguchi K, Tsuruo T (1995b) Identification of actin as a substrate of ICE and an ICE-like protease and involvement of an ICE-like protease but not ICE in VP-16-induced U937 apoptosis. Biochem Biophys Res Commun 217:1185-1192.

Mehlen P, Arrigo AP (1994) The serum-induced phosphorylation of 
mammalian hsp27 correlates with changes in its intracellular localization and levels of oligomerization. Eur J Biochem 221:327-334.

Mehlen P, Schulze-Osthoff K, Arrigo AP (1996a) Small stress proteins as novel regulators of apoptosis. Heat shock protein 27 blocks fas/ apo-1- and staurosporine-induced cell death. J Biol Chem 271:16510-16514.

Mehlen P, Kretz-Remy C, Preville X, Arrigo AP (1996b) Human hsp27, Drosophila hsp27 and human alphaB-crystallin expression-mediated increase in glutathione is essential for the protective activity of these proteins against TNFalpha-induced cell death. EMBO J 15:2695-2706.

Mehlen P, Hickey A, Weber LA, Arrigo A (1997) Large unphosphorylated aggregates as the active form of hsp 27 which controls intracellular reactive oxygen species and glutathione levels and generates a protection against TNF $\alpha$ in NIH-3Y3-ras cells. Biochem Biophys Res Commun 241:187-192.

Mellman IS, Plutner H, Steinman RM, Unkeless JC, Cohn ZA (1983) Internalization and degradation of macrophage $\mathrm{Fc}$ receptors during receptor-mediated phagocytosis. J Cell Biol 96:887-895.

Moore A, Donahue CJ, Bauer KD, Mather JP (1998) Simultaneous measurement of cell cycle and apoptotic cell death. Methods Cell Biol $57: 265-278$.

Morino M, Tsuzuki T, Ishikawa Y, Shirakami T, Yoshimura M, Kiyosuke Y, Matsunaga K, Yoshikumi C, Saijo N (1997) Specific expression of HSP27 in human tumor cell lines in vitro. In Vivo 11:179-184.

Mukherjee S, Ghosh RN, Maxfield FR (1997) Endocytosis. Physiol Rev 77:759-803.

Multhoff G, Hightower LE (1996) Cell surface expression of heat shock proteins and the immune response. Cell Stress Chaperone 1:167-177.

Muzio M, Chinnaiyan AM, Kischkel FC, O'Rourke K, Shevchenko A, Ni J, Scaffidi C, Bretz JD, Zhang M, Gentz R, Mann M, Krammer PH, Peter ME, Dixit VM (1996) FLICE, a novel FADD homologous ICE/CED-3-like protease, is recruited to the CD95 (Fas/Apo-1) deathinducing signaling complex. Cell 85:817-827.

Piselli P, Vendetti S, Poccia F, Cicconi R, Mattei M, Bolognesi A, Stirpe F, Colizzi V (1995) In vitro and in vivo efficacy of heat shock protein specific immunotoxins on human tumor cells. J Biol Regul Homeost Agents 9:55-62.

Poccia F, Piselli P, Di Cesare S, Bach S, Colizzi V, Mattei M, Bolognesi A, Stirpe F (1992) . Recognition and killing of tumor cells expressing heat shock protein $65 \mathrm{kD}$ with immunotoxins containing saporin. $\mathrm{Br} \mathbf{J}$ Cancer 66:427-432.

Provis JM, Penfold PL, Edwards AJ, van Driel D (1995) Human retinal microglia: expression of immune markers and relationship to the glia limitans. Glia 14:243-256.

Raffray M, Cohen GM (1991) Bis(tri-n-butyltin)oxide induces programmed cell death (apoptosis) in immature rat thymocytes. Arch Toxicol 65:135-139.

Reichlin M (1995) Cell injury mediated by autoantibodies to intracellular antigens. Clin Immunol Immunopathol 76:215-219.

Reichlin M (1998) Cellular dysfunction induced by penetration of autoantibodies into living cells: cellular damage and dysfunction mediated by antibodies to dsDNA and ribosomal $\mathrm{P}$ proteins. Autoimmunity 11:557-561.

Riabowol K, Mizzen L, Welch WJ (1988) Heat shock is lethal to fibroblasts microinjected with antibodies against hsp70. Science 242:433-436.

Ronda N, Gatti R, Orlandini G, Borghetti A (1997) Binding and internalization of human IgG by living cultured endothelial cells. Clin Exp Immunol 109:211-216.

Samali A, Cotter TG (1996) Heat shock proteins increase resistance to apoptosis. Exp Cell Res 223:163-170.

Scanlon M, Laster SM, Wood JG, Gooding LR (1989) Cytolysis by tumor necrosis factor is preceded by a rapid and specific dissolution of microfilaments. Proc Natl Acad Sci USA 86:182-186.

Schett G, Xu Q, Amberger A, Van der Zee R, Recheis H, Willeit J, Wick G (1995) Autoantibodies against hsp60 mediates endothelial cytotoxicity. J Clin Invest 96:2569-2577.

Schmid SL (1992) The mechanism of receptor-mediated endocytosis: more questions than answers. BioEssays 14:589-596.

Schnitzer J, Scherer J (1990) Microglial cell responses in the rabbit retina following transection of the optic nerve. J Comp Neurol 302:779-791.

Seigel GM (1996) Establishment of an E1A-immortalized retinal cell culture. In Vitro Cell Dev Biol Anim 32:66-68.

Sheller RA, Smyers ME, Grossfeld RM, Ballinger ML, Bittner GD (1998) Heat-shock proteins in axoplasm: high constitutive levels and transfer of inducible isoforms from glia. J Comp Neurol 396:1-11.

Slee EA, Harte MT, Kluck RM, Wolf BB, Casiano CA, Newmeyer DD, Wang HG, Reed JC, Nicholson DW, Alnemri ES, Green DR, Martin SJ (1999) Ordering the cytochrome c-initiated caspase cascade: hierarchical activation of caspases-2, -3, -6, -7, -8 and -10 in caspase-9dependent manner. J Cell Biol 144:281-292.

Song Q, Wei T, Lees-Miller S, Alnemri E, Watters D, Lavin MF (1997) Resistance of actin to cleavage during apoptosis. Proc Natl Acad Sci USA 94:157-162.

Srivastava PK (1994) Heat shock proteins in immune response to cancer: the fourth paradigm. Experientia 50:1054-1060.

Tezel G, Wax MB (1999) Inhibition of caspase activity in retinal cell apoptosis induced by various stimuli, in vitro. Invest Ophthalmol Vis Sci 40:2660-2667.

Tezel G, Seigel GM, Wax MB (1998) Autoantibodies to small heat shock proteins in glaucoma. Invest Ophthalmol Vis Sci 39:2777-2787.

Tezel G, Hernandez MR, Wax MB (2000) Immunostaining of heat shock proteins in the retina and optic nerve head of normal and glaucomatous eyes. Arch Ophthalmol 118:511-518.

Thornberry NA, Bull HG, Calaycay JR, Chapman KT, Howard AD, Kostura MJ, Miller DK, Molineaux SM, Weidner JR, Aunins J, Elliston KO, Ayala JM, Casano FJ, Chin J, Ding GJ-F, Egger LA, Gaffney EP, Limjuco G, Palyha OC, Raju SM, Rolando AM, Salley JP, Yamin T-T, Lee TD, Shively JE, MacCross M, Mumford RA, Schmidt JA, Tocci MJ (1992) A novel heterodimeric cystein protease is required for interleukin-1 $\beta$ processing in monocytes. Nature 356:768-774.

Tsukidate K, Yamamoto K, Snyder JW, Farber JL (1993) Microtubule antagonists activate programmed cell death (apoptosis) in cultured rat hepatocytes. Am J Pathol 143:918-925.

Tytell M, Greenberg SG, Lasek RG (1986) Heat shock-like protein is transferred from glia to axon. Brain Res 363:161-164.

van Engeland M, Kuijpers HJH, Ramaekers FCS, Reutelingsperger CPM, Schutte B (1997) Plasma membrane alterations and cytoskeletal changes in apoptosis. Exp Cell Res 235:421-430.

Villa PG, Henzel WJ, Sensenbrenner M, Henderson CE, Pettmann B (1998) Calpain inhibitors, but not caspase inhibitors, prevent actin proteolysis and DNA fragmentation during apoptosis. J Cell Sci 111:713-722.

Wagstaff MJ, Collaco-Moraes Y, Smith J, de Belleroche JS, Coffin RS, Latchman DS (1999) Protection of neuronal cells from apoptosis by hsp27 delivered with a Herpes Simplex virus-based vector. J Biol Chem 274:5061-5069.

Wax MB, Tezel G, Edward DP (1998) Clinical and pathological findings of a patient with normal pressure glaucoma. Arch Ophthalmol 116:993-1001.

Welch WJ, Suhan JP (1985) Morphological study of the mammalian stress response: characterization of changes in cytoplasmic organelles, cytoskeleton, and nucleoli and appearance of intranuclear actin filaments in rat fibroblasts after heat-shock treatment. J Cell Biol 101:1198-211.

Wickstrom ML, Khan SA, Haschek WM, Wyman JF, Eriksson JE, Schaeffer DJ, Beasley VR (1995) Alterations in microtubules, intermediate filaments and microfilaments induced by microcystin-LR in cultured cells. Toxicol Pathol 23:326-337.

Wulf E, Deboben A, Bautz FA, Faulstich H, Wieland T (1979) Fluorescent phallotoxin, a tool for the visualization of cellular actin. Proc Natl Acad Sci USA 76:4498-4502.

Yanase K, Smith RM, Puccetti A, Jarett L, Madaio M (1997) Receptormediated cellular entry of nuclear localizing anti-DNA antibodies via myosin 1. J Clin Invest 100:25-31.

Young DB (1992) Heat-shock proteins: immunity and autoimmunity. Curr Opin Immunol 4:396-400. 